\title{
Program Online Scholarship Competition sebagai Wujud Partisipasi Penciptaan Generasi Emas Indonesia 2045
}

\author{
Iman Indrati ${ }^{1}$, Muhammad Islam ${ }^{2}$, Adianti Paramita ${ }^{3}$ \\ ${ }^{1}$ Program Manajemen Service, Universitas Trisakti, Jakarta, Indonesia \\ 2 Program Ilmu Komputer, Universitas Budi Luhur, Jakarta, Indonesia \\ 3Program Manajemen Keuangan, Universitas Trisakti, Jakarta, Indonesia
}

\section{Keywords: \\ online scholarship \\ competition (OSC); \\ Indonesia Golden \\ generation}

\section{Kata kunci:}

online scholarship competition (OSC); generasi emas Indonesia

Alamat Korespondensi:

E-mail: pecalangbali@yahoo.com (Iman Indrati)

\begin{abstract}
This study aims to evaluate the OSC Program in terms of the mechanism of obtaining scholarships through the online scholarship competition program, and the obstacles faced when screening scholarship candidates. Field observations and interviews are used to collect data, and PESTEL and SWOT techniques are collaborated to identify the strengths, weaknesses, opportunities, and threats. The results show that this program has legitimacy and is officially supported by the Ministry of Research, Technology and Higher Education. Futhermore, OSC has a very clear, segmented and national target market. For private universities and sponsorships that are incorporated can raise the brand image of PTS and scholarship fund companies.
\end{abstract}

\begin{abstract}
Abstrak:. Penelitian ini bertujuan untuk mengevaluasi Program OSC dari sisi mekanisme mendapatkan beasiswa melalui program online scholarship competition, dan kendala yang dihadapi ketika menyaring para calon beasiswa dan manfaatnya sebagai bagian partisipasi pada visi generasi emas Indonesia 2045. Observasi lapangan dan wawancara digunakan untuk mengumpulkan data, dan teknik PESTEL dan SWOT dikolaborasi untuk mengindentifikasi berbagai kelebihan, kekurangan, peluang dan tatangan yang dihadapi. Hasil studi di lapangan menunjukkan bahwa program ini memiliki kemudahan, namun perlu dilakukan perluasan jaringan kerjasama perguruan tinggi lebih banyak lagi. Selain itu, OCS memiliki legitimasi dari Kemenristek dikti dan Kemendikbud. OSC memiliki target market sangat jelas, segmented dan mencakup Nasional dan dapat meningkatkan citra Perguruan Tinggi Swasta dan sponsorship yang menjadi mitra.
\end{abstract}

\section{Pendahuluan}

Saat ini manusia di berbagai negara sedang memasuki fase perjalanan kehidupan pada era Revolusi Industri 4.0. Semua teknologi di desain memenuhi kebutuhan kehidupan bagi setiap orang dari perspektif kehidupan pribadi, ruang sosial, hingga penyertaan revolusi perilaku kehidupan sosial masyarakat dunia. Globalisasi yang sudah terjadi menyebabkan tidak adanya batasan antar negara yang didukung oleh teknologi yang semakin canggih menyebabkan berbagai perkembangan yang terjadi di dunia dapat diakses dengan mudah. Memasuki era revolusi industri 4.0, dunia dihadapkan pada digital economy, kecerdasan buatan atau artificial intelligence, big data, semakin besarnya peran robot dan otomatisasi dalam proses produksi yang kemudian dikenal pula dengan istilah disruptive innovation. Di 
Indonesia, industri 4.0 sering disebut juga sebagai Making Indonesia 4.0. Istilah ini mengandung makna positif untuk memicu perkembangan Indonesia ke arah otomatisasi sistem melalui revitalisasi industri nasional secara keseluruhan, baik dari sisi teknologi, SDM, maupuan kesiapan pasar.

Era revolusi industri 4.0 membawa dunia mengaplikasikan kecerdasan buatan atau artificial intelligence (AI) yang berpotensi meningkatkan pendapatan global dan kualitas hidup bagi masyarakat dunia. Menurut World Economic Forum (WEF) menyebutkan bahwa revolusi industri 4.0 merupakan revolusi digital pada industri. Selain itu, AI juga menghasilkan harga murah dan kompetitif, meningkatkan efisiensi produktivitas, menurunkan biaya transportasi, komunikasi efektif, meningkatkan efektivitas logistik, rantai pasokan global, biaya perdagangan berkurang, membuka pasar baru, serta mendorong pertumbuhan ekonomi. Karenanya dibutuhkan pembentukan sumber daya manusia berkualitas sebagai asset penggerak keberhasilan Negara melalui pendidikan.

Pendidikan merupakan salah satu upaya keberlangsungan Negara dalam upaya melahirkan penerus Bangsa berkualitas, memiliki nilai etika sosial, nilai religius, berintegritas yang mencerminkan kepribadian Bangsa Indonesia. Pendidikan merupakan investasi membentuk sumber daya manusia berkualitas sehingga diharapkan mampu mengambil peran untuk pembangunan berbagai aspek kehidupan di suatu negara (Hamalik, 2008). Akses pendidikan dasar hingga perguruan tinggi merupakan salah satu upaya melahirkan generasi yang lebih berkualitas. Meski demikian, berdasarkan data Badan Pusat Statistik (BPS) tahun 2019, 40.51 persen tenaga kerja Indonesia masih berpendidikan Sekolah Dasar kebawah sehingga upaya untuk meningkatkan daya saing pekerja Indonesia di tengah situasi perdagangan bebas sekarang menjadi perhatian utama dari Kementerian Tenaga Kerja. Upaya yang dilakukan antara lain dengan pelatihan vikasi di Balai Latihan Kerja (BLK), program sertifikasi kompetensi yang dilakukan oleh Lembaga Sertifikasi Profesi (LSP) dengan pengawasan Badan Nasional Sertifikasi Profesi (BNSP).

Dicanangkannya Indonesia Emas 2045 mendatang, artinya kualitas sumber daya manusia menjadi dasar dari impian menjadi Indonesia emas tahun 2045 mendatang. Generasi emas (Kopeuw, 2015) memiliki dua pengertian: pertama, berkaitan dengan Bangsa yang besar dengan modalitas luar biasa; baik sumberdaya manusia, sumberdaya alam, kultural, maupun sumberdaya lainnya; sudah saatnya dikelola dan dimanfaatkan dengan sebaik-baiknya bagi kemakmuran dan kesejahteraan rakyat. Pendidikan mengambil peran sangat penting dan strategis dalam pembangunan bangsa. Kedua, generasi Emas Indonesia 2045 merupakan produk generasi baru yang Energik, Multritalenta, Aktif, dan Spiritual; yaitu generasi cerdas, siap bersaing di era modern, globalisasi dan penuh kompetitif. Energik artinya penuh energi atau bersemangat. Dengan bersemangat akan melahirkan rasa optimis dan memiliki kekuatan yang mengarahkan aktivitas hidupnya.

Selain upaya pemerintah, sektor swasta juga banyak yang memiliki kepedulian dengan pendidikan di Indonesia, salah satunya adalah Medcom.id yang menyelenggarkan program Online Scholarship Competition (OSC). Medcom.Id adalah media "News Video Portal", yang tampil dalam wujud multimedia berisi konten teks, foto, video, audio, dan videografis. Media Group News telah melaksanakan Program OSC Medcom.id dengan menyelenggarkan kompetisi beasiswa online pertama di Indonesia yang diinisiasi membuka peluang kepada pelajar untuk menempuh pendidikan perguruan tinggi. Dengan kata lain, OSC sebagai jembatan atau penghubung antara Perguruan Tinggi Swasta yang tergabung didalamnya dan sponsorship hadir memberikan kemudahan bagi putra putri berprestasi Indonesia dapat melanjutkan pendidikan hingga Strata 1 dengan beasiswa dari perguruan tinggi swasta. Program OSC ini diperuntukkan bagi siswa-siswi berprestasi dari berbagai lapisan masyarakat, tidak hanya dari kalangan kurang mampu tetapi siapapun siswa yang berprestasi bisa mengikuti program OSC.

Online Scholarship Competition (OSC) adalah program beasiswa online yang diadakan Medcom.id sejak tahun 2015. OSC merupakan kompetisi beasiswa online Indonesia yang memberikan peluang dan berbagai kemudahan bagi siswa/siswi Indonesia untuk melanjutkan pendidikan hingga jenjang Strata-1 (S1). Program ini mengembangkan inovasi dan memutus jalur seleksi sehingga peserta tidak lagi perlu datang kekampus/universitas untuk mendaftarkan diri dan mengikuti tes secara langsung. OSC diharapkan mampu menjadi daya dukung pendidikan tinggi yang memfasilitasi anak-anak berprestasi sebagai wujud partisipasi untuk mencapai cita-cita generasi emas Inodnesia tahun 2045. Sebagai program yang baru berjalan selama lima tahun, perlu dilakukan evaluasi mengenai pelaksanaan program, oleh karenanya, penelitian ini bertujuan untuk mengevaluasi Program OSC dari sisi mekanisme mendapatkan beasiswa melalui program online scholarship competition, dan kendala yang dihadapi ketika menyaring para calon beasiswa. Studi ini dapat menjadi bahan evaluasi dan perbaikan program bagi Medcom.id sehingga upaya perbaikan dapat terus dilakukan. 


\section{Metode}

Penelitian ini menggunakan pendekatan kualitatif yang dapat mengeksplorasi lebih dalam mengenai sebuah fenomena (Moleong, 2007). Dalam penelitian kualitatif ini dilakukan kajian yang holistik (menyeluruh) sehingga penelitian cenderung dilakukan dalam kurun waktu panjang. Observasi langsung di lapangan dan wawancara dilakukan untuk mengumpulkan data dan fakta di lapangan. Peneliti juga menggunakan analisis PESTEL untuk mempertimbangkan faktor - faktor permasalahan eksternal seperti Political, Economic, Social, Technology, Legal, dan Environment. Analisis PESTEL ini digunakan bersama SWOT analysis (Strength, Weaknesses, Opportunities and Threat analysis). Analisa PEST (Ward dan Peppard, dalam Setiawan dan Ilman, 2012) adalah analisis terhadap faktor lingkungan eksternal bisnis yang meliputi bidang politik, ekonomi, sosial dan teknologi. PEST digunakan untuk menilai pasar dari suatu unit bisnis atau unit organisasi. Analisis PESTEL adalah suatu teknik manajemen strategis untuk melihat faktor-faktor lingkungan luar/eksternal bisnis secara menyeluruh melalui berbagai sudut pandang karena metode ini dapat mengidentifikasi faktor - faktor eksternal yang mempengaruhi suatu organisasi.

\section{Hasil dan Pembahasan}

\section{Program OSC sebagai Partisipasi Penciptaan Generasi Emas Indonesia tahun 2045}

Istilah Generasi Emas Indonesia 2045 pertama kali di kemukakan oleh Menteri Pendidikan dan Kebudayaan pada sambutan Peringatan Hari Pendidikan Nasional pada tanggal 2 Mei 2012. Pernyataan ini merujuk pada pada bonus demografi pada tahun 2020-2035 yang diperoleh Indonesia. Tidak hanya itu, PricewaterhouseCoopers (PwC) juga memproyeksikan Indonesia di tahun 2050 akan menjadi negara dengan kekuatan ekonomi terbesar nomor empat di dunia setelah, Tiongkok, India dan Amerika Serika (Yusuf, 2017). Meski demikian, peluang ini tidak akan bisa terwujud tanpa sinergi antara pemerintah, masyarakat dan lembaga perguruan tinggi dalam upaya meningkatkan kapasitas dan kapabilitas SDM yang tersedia. Selain itu, pembentukan karakter SDM yang handal dan berbudaya juga menjadi tantangan tersediri bagi lembaga pendidikan di Indonesia (Masnur, 2011; Umairah, 2017).

Indonesia Emas 2045 merupakan impian besar tentang Indonesia yang unggul, maju bersaing dengan bangsa-bangsa lain.Meskipun pemerintah telah bekerja keras menggapai impian tersebut, namun pada kenyataannya masih ada saja yang melihat sektor pendidikan secara pragmatis dan ekonomis. Pendidikan dianggap sebagai pabrik raksasa yang harus menguntungkan secara ekonomi. Pendidikan senantiasa menjadi kawah candradimuka untuk mencetak generasi masa depan yang unggul, berkualitas, dan berakhlak mulia sehingga bermanfaat bagi diri, keluarga, masyarakat, negara, dan umat manusia secara keseluruhan. Dunia pendidikan senantiasa mengarah pada pencapaian tujuan, maka niscaya bangsa ini akan maju, sejahtera, dan berakhlak mulia melahirkan generasi masa depan yang unggul. Untuk mewujudkan impian tersebut, kunci utamanya pada kualitas manusianya.

Kesadaran dan kecerdasan kultural (awareness and intelligence cultural) merupakan faktor penting pembentukan dan pengembangan generasi emas atau generasi berkarakter pada masa depan. Berbagai permasalahan di dunia pendidikan di Indonesia seperti kekerasan yang terjadi di lingkungan sekolah, seks bebas, dan narkotika, yang kemudian berkolaborasi dengan permasalahan sosial lainnya seperti kemiskinan merupakan sebuah tantangan yang harus disikapi serius dalam upaya mewujudkan cita-cita generasi emas ini. Dibutuhkan strategi dan diagnosa yang cermat dan tepat untuk menyelesaikan persoalan ini yang melibatkan seluruh komponen, mulai dari pemerintah, sektor pendidikan, dan masyarakat secara umum (Ahyar, 2014). Langkah pertama dalam upaya mewujudkan generasi emas ini adalah meningkatkan aksesibilitas dan kualitas dunia pendidikan.

Sebagai negara dengan penduduk lebih dari 260 juta jiwa di tahun 2018 (BPS, 2018), Indonesia menjadi negara terbesar ke-empat dunia setelah Tiongkok, (1,42 miliar jiwa), India (1,37 miliar jiwa), dan Amerika Serikat (328 juta jiwa). Indonesia diprediksi memiliki bonus demografi yaitu 
jumlah penduduk usia produktif di tahun 2030 - 2040 lebih banyak dibandingkan dua kelompok usia lainnya itu penduduk usia tidak produktif yaitu berusia di bawah 15 tahun dan di atas 64 tahun. Pada periode tersenut, Indonesia di prediksi memiliki penduduk usia produktif lebih dari $60 \%$ dari total penduduk yang diperkirakan sebanyak 297 juta jiwa. Bonus demografi ini tidak akan memperoleh manfaat apa-apa bagi Indonesia jika tidak dilakukan serangkaian upaya untuk menyiapkan sumber daya manusia yang memiliki kualitas dari sisi pendidikan dan keterampilan sehingga memiliki daya saing untuk menghadapi pasar tenaga kerja yang semakin terbuka.

Berdasarkan siaran pers Kementerian PPN/Bappenas tahun 2017, Indonesia saat ini memiliki dua permasalahan utama, yaitu : pertama, tenaga kerja Indonesia saat ini masih didominasi oleh tenaga kerja yang berpendidikan sekolah menengaj pertam atau lebih rendah (63 persen). Kondisi tersebut memiliki dampak pada produktivitas dan daya saing tenaga kerja yang relatif rendah dibandingkan negara lainnya. Kedua, pendidikan dan keterampilan yang dimiliki tenaga kerja dinyatakan masih banyak yang tidak sesuai dengan kebutuhan industry dan dunia bisnis, sehingga menyebabkan daya serap industri menjadi rendah dikarenakan sulitnya mendapatkan tenaga kerja yang memenuhi kualifikasi yang diinginkan oleh industri.

Kebutuhan masyarakat akan pendidikan semakin meningkat seiring dengan kemajuan teknologi dan adanya pasar bebas ASEAN yang menjadikan tenaga kerja asing dapat masuk dengan bebas ke Indonesia. Kondisi ini menuntut pemerintah untuk meningkatkan keterampilan SDM masyarakat sehingga mampu bersaing dengan tenaga kerja yang berasal dari luar. Berbagai upaya yang dilakukan antara lain dengan memberikan keterampilan melalui Balai Latihan Kerja dan sertifikasi profesi bekerja sama dengan Badan Nasional Sertifikasi Profesi (BNSP). Selain pemerintah, swasta melalui program Corporate Social Responsibility (CSR) juga memberikan kontribusi melalui pemberian beasiswa seperti yang dilakukan oleh Medcom.id dengan program Online Scholarship Competition (OSC).

\section{Beasiswa}

Pengertian beasiswa (Lahinta, 2009) adalah pemberian berupa bantuan keuangan yang diberikan kepada perorangan yang digunakan demi keberlangsungan pendidikan. Beasiswa dapat diberikan oleh lembaga pemerintah, perusahaan ataupun yayasan. Adapun tujuan diberikannya beasiswa untuk menghasilkan sumber daya manusia berpotensi mempercepat pembangunan bangsa menuju kemandirian di tengah percaturan global, mewujudkan keadilandan demokratisasi,serta memberikan bantuan dana kepada mahasiswa yang mengalami kendala secara ekonomis maupun geografis. Pendapat serupa mengenai beasiswa (Murniasih, 2009) sebagai bentuk penghargaan kepada individu dapat melanjutkan pendidikan ke jenjang yang lebih tinggi. Pemberian beasiswa unggul kepada putra-putri terunggul bangsa Indonesia terseleksi disalurkan dengan perorangan atau badan / institusi pengusul dalam kerangka menyediakan insan Indonesia yang cerdas dan bersaing sesuai dengan visi Pendidikan Nasional 2045 yakni menciptakan generasi emas.

\section{Program Online Scholarship Competition (OSC)}

Medcom.id adalah media portal news yang memiliki kepedulian pada dunia pendidikan dengan meluncurkan Program Online Scholarship Competition (OSC) yang sudah dilaksanakan sejak 2015. OSC dengan konsepnya bertujuan untuk memudahkan putra-putri Indonesia untuk memperoleh pendidikan ke tingkat perguruan tinggi. Penyelenggaran OSC memasuki tahun kelima di tahun 2019 dan menyediakan 420 beasiswa, dan jumlah ini naik dari tahun sebelumnya yaitu sebanyak 360 beasiswa S1 yang akan dikompetisikan oleh ribuan mahasiswa di seluruh Indonesia.

Selain menjadi media untuk menyalurkan beasiswa, OSC juga ditujukan untuk menjadi media promosi dan komunikasi antara perguruan tinggi yang tergabung dalam program ini, diantaranya; Universitas Katolik Indonesia Atma Jaya, Universitas Mercu Buana, Universitas Muhammadiyah Prof. Dr. Hamka, Universitas Multimedia Nusantara, President University, Universitas Trisakti, Institute Teknologi Nasional (ITENAS), Universitas Kristen Maranatha, Telkom University, Universitas Kristen Duta Wacana, Universitas Kristen Satya Wacana, Universitas Gajayana, Universitas Islam Malang, 
Universitas Katolik Widya Mandala (UKWMS), UNUSA, Universitas 17 Agustus 1945, Universitas Ciputra, Universitas Muslim Indonesia, Universitas Warma Dewa Bali,Universitas Fajar, Dalam kerjasamanya, OSC Medcom memiliki kriteria Perguruan Tinggi Swasta (PTS) yang tergabung, yakni: PTS miliki rekam jejak yang baik, terakreditasi A / B, telah beroperasi minimal selama 8 tahun, memiliki Fakultas dan Program Studi yang beragam dan memiliki program beasiswa.

Medcom.id milik Media Group News, termotivasi meningkatkan peluang kepada siswa berprestasi tetapi kurang mampu secara ekonomi untuk melanjutkan pendidikan ke perguruan tinggi sehingga akses terhadap universitas jadi merata. Selain itu, OSC diharapkan dapat menjadi daya dukung pendidikan tinggi yang mampu memfasilitasi anak-anak berprestasi dari berbagai kalangan di seluruh Indonesia. Melihat tingginya angka calon mahasiswa tersebut, OSC melalui program jalur beasiswa tanpa harus datang ke kampus untuk mendaftarkan diri dan mengikuti tes secara langsung. OSC mempersingkat proses tersebut dengan metode online. Pendaftaran dan tes tahap awal melalui sistem online. Dengan dilibatkannya 21 perguruan tinggi swasta di sepuluh Kota, yakni; Jakarta, Tangerang, Depok, Cikarang, Bandung, Salatiga, Yogyakarta, Malang, Surabaya, Makassar). Dengan demikian, para peserta lebih leluasa memilih universitas favorit yang akses lebih mudah melanjutkan pendidikannya.

Tabel 1. Data OSC 2015-2018

\begin{tabular}{lccccc}
\hline \multicolumn{1}{c}{ Data } & Tahun & Tahun & Tahun & Tahun & Tahun \\
& $\mathbf{2 0 1 5}$ & $\mathbf{2 0 1 6}$ & $\mathbf{2 0 1 7}$ & $\mathbf{2 0 1 8}$ & $\mathbf{2 0 1 9}$ \\
\hline Penerimaan Beasiswa & 50 & 200 & 240 & 360 & 420 \\
Offline Test & 300 & 700 & 840 & 1.260 & - \\
Jumlah Peserta & 5.698 & 28.099 & 42.633 & 54.189 & - \\
$\begin{array}{l}\text { Visitor Website } \\
\text { Rasio Penerima dan Peserta }\end{array}$ & 253.278 & 824.706 & 1.245 .299 & 3.503 .861 & - \\
(persen) & 0.878 & 0.712 & 0.563 & 0.664 & \\
\hline & & & Sumber: data internal Medcom.id
\end{tabular}

Berdasarkan tabel yang disajikan di atas terlihat bahwa OSC mengalami Improvement yang sangat besar terhitung dari 4 kali penyelenggaraannya didukung platform Media Group News. Program ini didukung secara resmi Kemenristekdikti dan Kemendikbud telah memberikan penghargaan dan menobatkan OSC sebagai event beasiswa online pertama dan satu-satunya di Indonesia. OSC menjadi program yang dinantikan siswa-siswi Sekolah Menengah Atas dan memiliki target market sangat jelas, segmented dan mencakup Nasional. OSC merupakan event integrated campaign efektif, melingkupi Cross Platform Media, Offair, Engagement, Social Media yang melebihi nilai program OSC sendiri. Dampak yang terjadi akibat keberadaanProgram OSC Medcom.id dapat dianalis dengan PESTEL Analysis. Metode PESTEL bertujuan membahas faktor politik, ekonomi, sosial, teknologi, lingkungan, dan hukum yang memengaruhi saat ini. Analisis PESTEL mengidentifikasikan Program OSC, sebagai berikut:

Prorgram OSC dalam perspektif politik mengacu pada pentingnya kesadaran tiap komponen bangsa untuk mensukseskan generasi emas Indonesia 2045 sebagai bagian yang tidak terpisahkan dari tujuan dan cita-cita bangsa Indonesia yaitu "mencerdasakan kehidupan bangsa". Dalam konteks ini, OCS memiliki keyakinan bahwa masalah pendidikan merupakan tanggung jawab bersama dan bukan semata-mata diserahkan kepada pemerintah. Pemerintah melalui Kementerian Pendidikan dan Kebudayaan dan Kementerian Keuangan mengembangkan Layanan Beasiswa dan Pendanaan Riset Indonesia (LPDP) yang menyediakan banyak kesempatan beasiswa kepada siswa-siswa berprestasi dari tingkat S1 sampai dengan S3. Dari sisi politik, tujuan akhir kegiatan OCS ini dalam dalam rangka menjaga keutuhan NKRI melalui peningkatan kecerdasan masyarakat sesuai dengan amat Undang-Undang Dasar 1945.

Berikutnya dari perspektif ekonomi, program OCS telah mengalami pengembangan dari tahun ke tahun, mulai dari kemudahan perdaftaran, proses seleksi, sampai dengan penempatan pemenang pada perguruan tinggi mitra. Selain itu, dalam dua tahun terakhir, perguruan tinggi yang 
bekerjasama semakin banyak dan mencapai dua puluh satu perguruan tinggi swasta yang ada di Indonesia. Sejalan dengan itu, terjadi juga peningkatan sponsorship yang disebabkan karena program ini dianggap cukup berhasil, memiliki target market dan segmentasi yang jelas. Dengan demikian dapat dinyatakan bahwa dari sisi ekonomi, OCS memang dirancang untuk menjaring banyak perguruan tinggi swasta dan lembaga sponsor untuk bekerja secara bersama mendukung agenda pemerintah untuk menciptakan generasi emas Indonesia 2045 melalui pemberian beasiswa kepada siswa yang berprestasi.

Tabel 2. Analisa PESTEL Program OSC Medcom.id

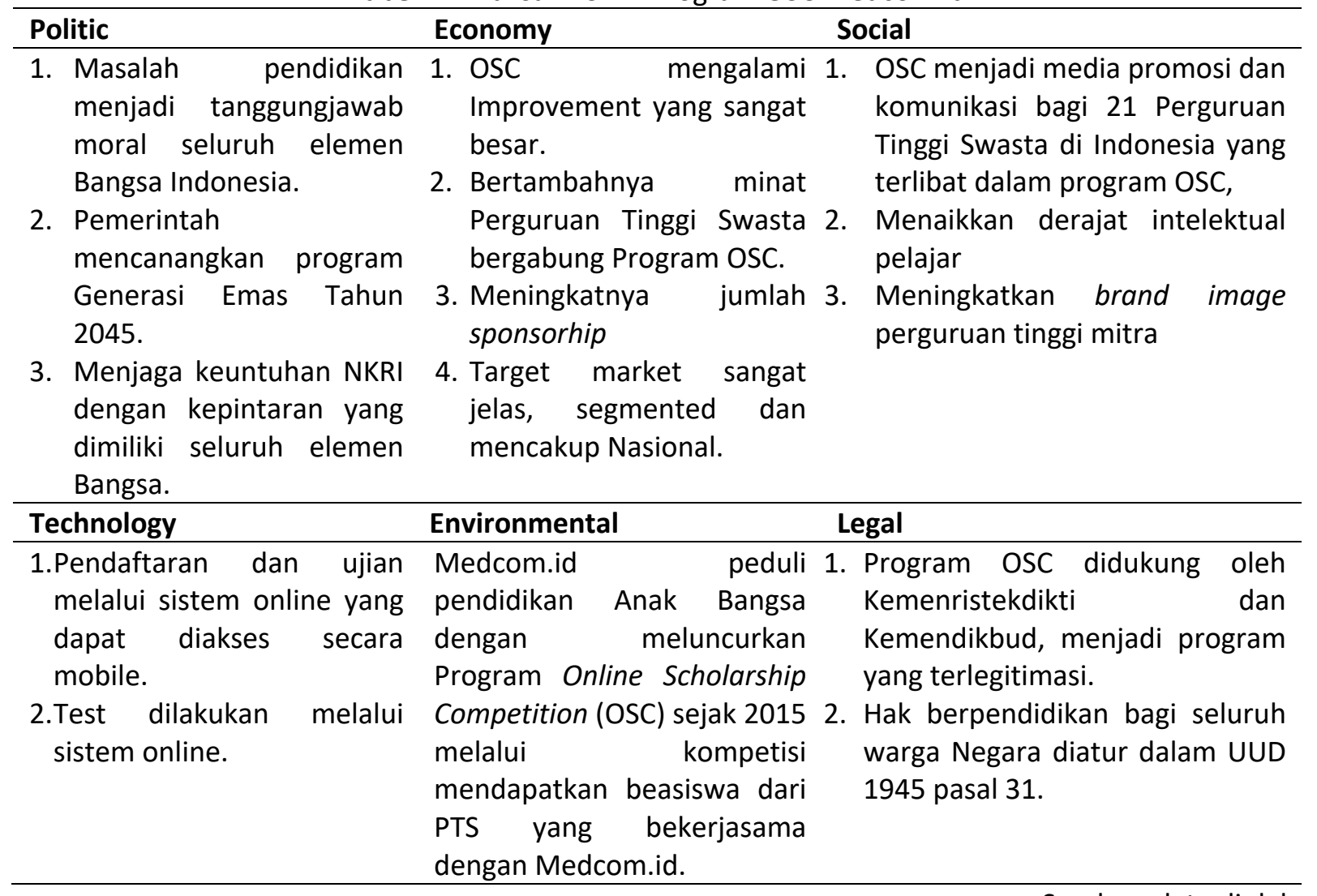

Sumber: data diolah

Perspektif sosial mengacu pada bagaimana program ini dapat memberikan pengaruh sosial kepada masyarakat maupun penyelenggara. Dari sisi peserta, keikutsertaan siswa dalam program OCS ini dapat menaikkan derajat intelektualitas siswa dan status sosialnya di masyarakat. Berikutnya, dari sisi penyelenggara dan perguruan tinggi, OCS dapat dijadikan media promosi dan meningkatkan citra perguruan tinggi dalam upaya memberikan kesempatan yang luas kepada semua siswa yang memiliki kapasitas melanjutkan pendidikan. Oleh karenanya, OCS dalam konteks ini dapat memberikan dampak sosial yang baik kepada penyelenggara, perguruan tinggi mitra yang tergabung dalam program, maupun pada siswa yang mendapatkan beasiswa.

Perspektif teknologi mengacu bagaimana OCS memanfaatkan teknologi informasi untuk memudahkan siswa mempeperoleh peluang melanjutkan pendidikan melalui beasiswa. Seluruh aktivitas seleksi dilaksanakan secara online sehingga dapat dilakukan secara efisien dan diakses secara luas di seluruh Indonesia.

Perspektif lingkungan mengindikasikan bahwa OCS Medcom.id peduli pendidikan Anak Bangsa dengan meluncurkan Program Online Scholarship Competition (OSC) sejak 2015 melalui kompetisi mendapatkan beasiswa dari PTS yang bekerjasama dengan Medcom.id. Terakhir dari perspektif legalitas, program OSC didukung oleh Kemenristekdikti dan Kemendikbud, menjadi 
program yang terlegitimasi. Selain itu, OCS mendukung hak berpendidikan bagi seluruh warga Negara diatur dalam UUD 1945 pasal 31.

Hasil analisis yang ditampilkan pada Tabel PESTEL menunjukkan bahwa Program OSC mempengaruhi tingkat pendidikan dapat memajukan teknologi dan peningkatakan perekonomian Negara Indonesia. Dengan program pendidikan beasiswa berbasis online ini memacu para pengusaha dan Perguruan Tinggi untuk ikut andil mewujudkan Bangsa Pintar dan Berbudaya. Tentu saja secara legal, Pemerintah memberikan dukungan dan terus menerus pada program yang dilakukan secara mandiri oleh perusahaan swasta sebagai wujud partisipasi menciptakan generasi bangsa yang lebih baik di masa depan.

Tabel 3. Analisa SWOT Program OSC Medcom.id

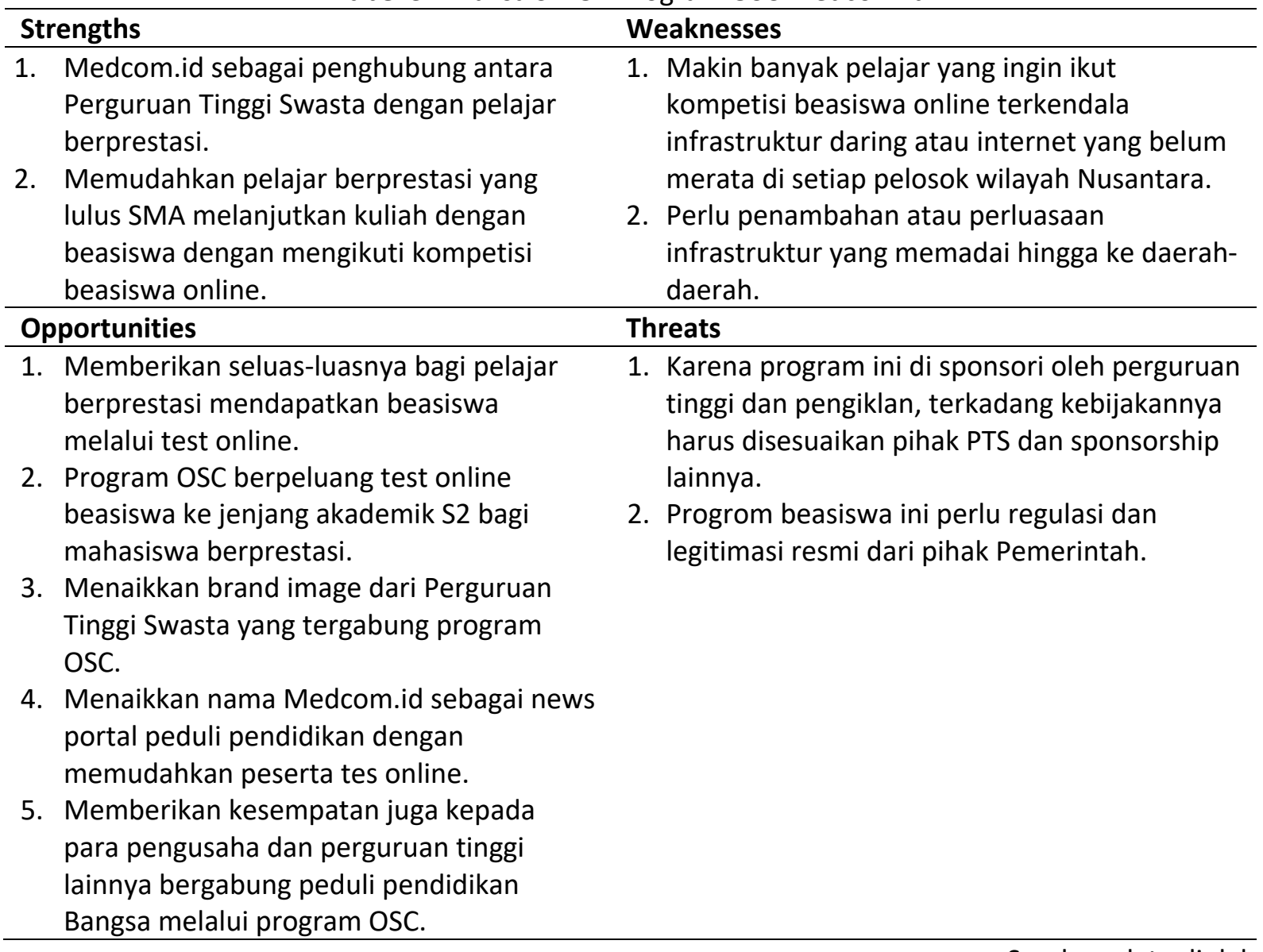

Sumber: data diolah

\section{Mekanisme Beasiswa Program Online Scholarship Competition (OSC)}

Tahun 2018 Medcom menyelenggarakan tes online yang diikuti hampir 50 ribu pelajar lulus Sekolah Menengah Atas dari seluruh Indonesia. Dari 50 ribuan peserta ini, sebanyak 360 pelajar terpilih. Beasiswa yang diberikan dengan biaya full selama 8 semester atau 4 tahun masa kuliah. Mekanisme mengikuti Program OSC Medcom.id sangat mudah dengan mengikuti petunjuk yang ada di website https://osc.medcom.id.

Calon peserta pertama-tama diminta untuk mengisi informasi yang meliputi: pas photo, nama lengkap, tanggal lahir, alamat, nomor handphone, asal sekolah, dan provinsi, dan nomor induk siswa (NIS). Setelah peserta mendaftarkan diri, maka berikutnya akan dikirim konfirmasi mengenai registrasi. 


\section{Kendala yang dihadapi ketika seleksi para calon beasiswa dan penempatan mahasiswa terseleksi.}

Berdasarkan hasil wawancara dengan peserta, beberapa kendala yang masih terjadi dalam proses seleksi dan penempatan ini adalah dari sisi infrastruktur. Program ini belum secara maksimal menjangkau seluruh wilayah Indonesia dikarenakan keterbatasan akses internet yang berbeda antar daerah. Selain itu, pilihan perguruan tinggi yang ada masih terkonsentrasi di pulau Jawa sehingga kesempatan pelajar yang ingin melanjutkan studi di wilayah lainnya belum tersedia secara maksimal. Menindaklanjuti permasalahan ini, pihak Medcom.id perlu memperluas jaringan kerjasama dengan perguruan tinggi swasta di seluruh Indonesia. Penambahan jaringan kerjasama ini dapat meningaktkan kuota jumlah peserta beasiswa karena tingginya minat peserta dalam program ini. Seperti ditampilkan pada tabel 1 Data OSC, rasio perbandingan antara jumlah penerima beasiswa dengan jumlah peserta masih relative kecil yaitu sebesar $0.878 \%$ (2015), $0.712 \%$ (2016), 0.563\% (2017) dan 0.664\% (2018).

\section{Simpulan}

Penelitian ini bertujuan untuk mengevaluasi Program OSC dari sisi mekanisme mendapatkan beasiswa melalui program online scholarship competition, dan kendala yang dihadapi ketika menyaring para calon beasiswa. Hasil studi di lapangan menunjukkan bahwa program ini memiliki legitimasi dan didukung secara resmi Kemenristek dikti dan Kemendikbud. OSC memiliki target market sangat jelas, segmented dan mencakup Nasional. Bagi Perguruan Tinggi Swasta dan sponsorship yang tergabung dapat menaikkan brand image PTS dan perusahaan pemberi dana beasiswa. Program ini merupakan salah satu wujud partisipasi perguruan tinggi bekerjasama dengan perusahaan swasta untuk mewujudkan generasi emas Indonesia tahun 2045.

Mekanisme mendapatkan beasiswa melalui program OSC relative mudah melalui mekanisme seleksi secara online di tempat masing-masing pendaftar. Pelajar yang lulus akan disebar pada dua puluh satu perguruan tinggi swasta. Bagi pelajar yang berhasil lolos kompetinsi OSC, pemenangnya akan mendapatkan bebas uang pangkal seratus persen, bebas uang semester selama 4 tahun dan dan sertifikat. Kendala yang dihadapi ketika menyaring terletak pada masalah infrastruktur yang masih kurang menjangkau peserta dari daerah terpencil. Hal tersebut menjadi pemikiran bagi Medcom.id menambah infrastruktur agar pelajar berprestasi yang ingin meraih beasiswa melalui OSC dapat berkompetinsi tanpa terhalang teknologi karena letak geografisnya yang sulit terjangkau jejaring atau internet. Selain itu perlu juga dipertimbangkan untuk memperluas jaringan kerjasama dengan perguruan tinggi swasta secara merata seperti di Sumatera, Kalimantan, dan Sulawesi.

Studi ini memiliki keterbatasan hanya melakukan penelitian di kegiatan Medcom.id dalam melaksanakan program OSC dan data diperoleh dari pihak Medcom.id serta pengamatan penelitian selama berjalannya program OSC. Namun peneliti tidak dapat memantau langsung kegiatan mahasiswa yang sudah berkuliah di Perguruan Tinggi para pemenang ditempatkan karena faktor waktu dan peserta yang sudah tersebar di berbagai daerah. Untuk penelitian selanjutnya, dapat meneliti kondisi mahasiswa OSC yang telah kuliah di Perguruan Tinggi tersebut, mulai dari kondisi, nilai dan attitude serta kegiatan mahasiswa berprestasi hasil saring program OSC. Selain itu, peneliti selanjutnya juga bisa meneliti atau menganalisa perguruan tinggi pemberi beasiswa OSC yang menerima mahasiswa beasiswa hasil rekrutannya, brand image perguruan tinggi tersebut.

\section{Ucapan terimakasih}

Sehubungan dengan terselesaikannya artikel ini, kami mengucapkan terima kasih kepada manajemen Media Group News yang telah memberikan sumbangsih pemikiran dan data terkait Program OSC yang diselenggarakan Medcom.id beserta para sponsorship yang terlibat Program Kompetisi beasiswa online. Terima kasih Kami sampaikan kepada: 1) Avi Pranantha (Direktur HR Media Group News), 2) Muhammad Islam (Direktur Digital Bussiness Media Group News), 3) Manajemen Medcom.id, 4) Manajemen Media Group News 


\section{Daftar Pustaka}

Ahyar, M. 2014. Konstruksi Edukasi Generasi Emas Dan Peran Lembaga Pendidikan (Antara Kemiskinan Dan Kekerasan). El-Hikam, 7(2), 287-308.

Hamalik, O. 2008. Kurikulum dan Pembelajaran. Jakarta: Sinar Grafik.

Kopeuw, P M. 2015. Mimpi Memiliki Generasi Emas. Jakarta: Sentani.

Moleong, L. J. 2007. Metodologi penelitian kualitatif edisi revisi. Bandung: PT Remaja Rosdakarya

Murniasih, E. 2009. Buku Pintar Beasiswa, First Edit. Jakarta: Gagas Media

Muslich, M. 2011. Pendidikan Karakter Menjawab Tantangan Krisis Multidimensional. Jakarta:Bumi Aksara

Kementerian PPN dan Bapenas, 2017. Siaran Pers. Diakses melalui https://www.bappenas.go.id/files/9215/0397/6050/Siaran Pers (Diakses 18 Juli 2019).

Kamus Besar Bahasa Indonesia. [Online]. kbbi.kemdikbud.go.id/entri/religius.

PDSPK Kemendikbud. 2017. Rangkuman Statistik Pendidikan Dasar dan Menengah. Jakarta: Pusat Data dan Statistik Pendidikan dan Kebudayaan.-Jakarta: Setjen, Kemendikbud

Setiawan, A., \& Ilman, B. 2012. Perencanaan Strategik Sistem Informasi pada Perusahaan Penerbitan dengan Metode Ward \& Peppard: Studi Kasus pada Penerbit Rekayasa Sains Bandung. Journal of Technology Management, 11(3), 115715.

Situs Resmi OSC: https://osc.medcom.id/

Umairah, S. J. 2017. Rekonstruksi Nilai-Nilai Religius Sebagai Landasan Menyongsong Generasi Emas 2045. PROCEEDING IAIN Batusangkar, 1(2), 361-368.

Yusuf, M. (2017, October). Pendidikan Karakter Menuju Generasi Emas 2045. In Prosiding Seminar Nasional Inovasi Pendidikan. 